\title{
The Pharmacology of Beta-Adrenergic Blocking Agents
}

\author{
By Benedict R. Lurchesi and I feirhton S. Whitsit"I
}

\section{A. Development of the Concept of Adrenergic Rechitors}

$\mathrm{T}$ $\mathrm{HE}$ endogenously released neurotransmitter substance, norepinephrine, or an injected sympathomimetic amine, ultimately exerts its actions on an organ system by combining with an area of the effector cell termed the adrenergic "receptor site." That drugs and neural chemical mediators react with specific receptors in living tissues was suggested by Langley ${ }^{55}$ in 1905, who suggested that effector cells contain both excitatory (motor) and inhibitory "receptor substances." The response of a tissue to epinephrine was dependent upon the relative proportions of excitatory and inhibitory receptors present. This hypothesis received support in 1906 from the studies of Dale ${ }^{2-5}$ on the adrenergic blocking activity of the ergot alkaloids, in which it was demonstrated that the excitatory actions of epinephrine, with the exception of its cardiostimulatory actions, were antagonized or even reversed by ergot. However, ergot was without effect on the inhibitory actions of epinephrine. It remained for Ahlquist ${ }^{2}$ in 1948 to define clearly the dual adrenergic receptor hypothesis. Ahlquist's concept was based on the premise that two types of adrenergic receptors could be demonstrated by differing rank orders of potency within a single series of closely related agonists on a variety of different adrenergically controlled functions. A total of six sympathomimetic amines were studied for their ability to produce vasoconstriction, uterine muscle stimulation, contraction of the nictitating membrane, pupillary dilatation, and inhibition of gastrointestinal smooth muscle. A consistent order of potency emerged among the six sympathomimetic amines, in which norepinephrine was the most potent and isoproterenol the least potent of the amines studied. This order of potency was found to be reversed when the same agonists were tested for their ability to produce vasodilatation, inhibition of the uterus, and cardiac stimulation. On the basis of these results, Ahlquist ${ }^{2}$ postulated the existence of two distinct types of adrenergic receptors, in agreement with the earlier observations of Dale ${ }^{2.5}$ and proposed the terms alpha and beta adrenergic receptors only because "excitatory" and "inhibitory" did not describe them properly. "Alpha" was applied to those adrenergic receptors most responsive to norepinephrine and least responsive to isoproternol (Isuprel), and "beta" was applied to those receptors most responsive to isoproterenol and least responsive to norepinephrine.

The classification of receptors in different organs is summarized in Table 1.

From The University of Michigan Medical School, Department of Pharmacology, Ann Arbor, Michigan 48104.

The original work referred to in this review was supported by U. S. Public Health research grant HE-05806.

Benedict R. Lucchesi, M.D., PH.D.: Associate Professor of Pharmacology, University of Michigan Medical School. Leichton S. Whiтsitt, Pr.D.: Teaching Fellow, Department of Pharmacology, University of Michigan Medical School, Ann Arbor, Michigan. 
Table 1.-Classification of Adrenergic Receptors in Selected Organ Systems

\begin{tabular}{|c|c|c|}
\hline Organ & Responses & Receptor type \\
\hline Heart & $\begin{array}{l}\text { increased rate (autunaticity) } \\
\text { increased force } \\
\text { increased rate A-V conduction } \\
\text { coronary artery constriction } \\
\text { coronary artery dilatation } \\
\text { metabolism (glycogenolysis) }\end{array}$ & $\begin{array}{l}\text { beta } \\
\text { beta } \\
\text { beta } \\
\text { alpha } \\
\text { beta } \\
\text { beta }\end{array}$ \\
\hline Blond ressels & $\begin{array}{l}\text { arteriolar constriction } \\
\text { venoconstriction } \\
\text { arteriolar dilatation }\end{array}$ & $\begin{array}{c}\text { alpha } \\
\text { alpha \& beta } \\
\text { beta }\end{array}$ \\
\hline Lung & bronchiolar dilatation & bet:a \\
\hline Liver & $\begin{array}{l}\text { slycogenolysis } \\
\text { potassiun release. }\end{array}$ & $\begin{array}{c}\text { alpha;beta } \\
\text { alphal }\end{array}$ \\
\hline Adipose tissue & lipolysis & beta \\
\hline
\end{tabular}

${ }^{*}$ Species variation exists. The hepatic receptor mediating glycogenolysis in man has not been clefined.

Although the list is incomplete it will serve as a basis for a subsequent discussion of beta-adrenergic receptor blocking agents.

With reference to Table 1 it should be pointed out that according to current concepts there are no vascular beta-adrenergic receptors that are innervated directly (except perhaps in the coronary arteries) and that the venocontrictor and vasoconstricter responses to adrenergic nerve stimulation are mediated by alpha-adrenergic receptors. On the other hand arteriolar dilatation as a result of heta-adrenergic receptor activation may be elicited by circulating catecholamines, since there is no evidence to date to indicate a nerve mediated beta-adrenergic vasodilatation. This is in marked contrast to the situation which exists in the heart, where the adrenergically mediated responses (sympathetic nerve stimulation) of increased heart rate and contractile force are due to activation of beta-adrenergic receptors; the latter respond also in a similar manner to circulating catecholamines.

\section{B. Deyelopaient of Beta-Adrenfergic Receptor Blocking Agents}

The classical alpha-adrenergic receptor blocking drugs such as phenoxybenzamine (Dibenzyline) and phentolamine (Regitine) prevent only the responses mediated by alpha-adrenergic receptors. When Ahlquist proposed his dual receptor hypothesis, the available adrenergic receptor blocking agents were capable of blocking only alpha-adrenergic receptors. Of necessity, the Ahlquist method of characterizing adrenergic receptors, based upon rank order of agonist potency, was merely suggestive and received little attention until the discovery of dichloroisoproterenol (DCI) by Powell and Slater ${ }^{5 B}$ in 1958. DCI was shown to antagonize the inhibitory effects, i.e., beta-adrenergic receptor mediated responses, of sympathomimetic amines on the tracheobronchial system, blood vessels, uterus, and intestine, but blocked neither 


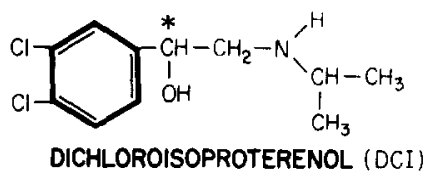<smiles>CC(C)NCCc1cc2ccccc2cc1O</smiles>

PRONETHALOL (Nethalide, Alderlin)<smiles>CC(C)NCC(O)c1ccc(NC(=O)O[Na])cc1</smiles>

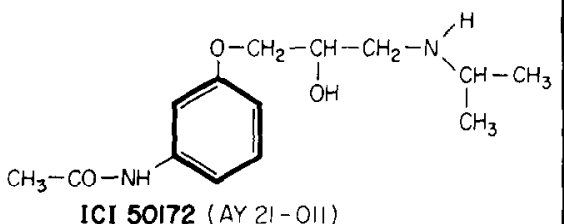<smiles>CC(C)NCC(O)CNC(C)C</smiles>

H 56/28 (Alprenolol)<smiles>CC(C)NCC(O)COc1cccc2ccccc12</smiles><smiles>COc1ccc(OC)c(C(O)C(C)NC(C)(C)C)c1</smiles>

Fig. 1-Structural formulas of several agents reported to possess beta-adrenergic receptor blocking activity. The presence of an asymmetric carbon atom (asterisk) in the alkyl side chain of each compound gives rise to dextro- and levo-rotatory optical isomers of which only the levo-isomer possesses beta-receptor blocking activity.

the vasopressor effect of sympathomimetic amines nor the adrenergicallyinduced contraction of the nictitating membrane. In addition DCI depressed the rate and force of contraction of the frog heart and decreased the positive inotropic and chronotropic effects of epinephrine. In the same year (1958) Moran and Perkins ${ }^{i t}$ confirmed the blockade of adrenergic vasodilatation by DCI reported previously by Powell and Slater. ${ }^{86}$ In addition they demonstrated that DCI produced a highly specific cardiac adrenergic receptor blockade in the dog heart and in the isolated perfused rabbit heart; i.e., DCI specifically inhibited the positive inotropic and chronotropic responses to adrenergic nerve stimulation and the exogenously administered catecholamines. The specificity of the blockade was demonstrated by the inability of DCI to prevent the augmentation of cardiac contractile force produced by calcium chloride, ouabain or theophylline at a time when adrenergic stimuli were antagonized. The study by Moran and Perkins ${ }^{74}$ represented the first description of specific adrenergic blockade of the mammalian heart and supported Ahlquist's hypothesis that the cardiac inotropic and chronotropic adrenergic receptors are of the beta type; receptors which subserve inhibitory functions in other organs, in contrast to the alpha receptors which subserve sympathetic excitatory responses in all organs except the heart.

Since the introduction of DCI, numerous analogs of isoproterenol, as well as many compounds of differing chemical structure have been described as possessing beta-adrenergic receptor blocking activity. The interested reader should refer to the publications by Biel and $\mathrm{Lum}^{\top}$ and by Ariens' for a dis- 
cussion of the structure activity relationships and pharmacology of the many members belonging to this new class of pharmacological agents.

The clinical use of DCI reported by Riddell et al. ${ }^{94}$ was limited because the drug, as shown by Moran and Perkins ${ }^{74}$ possessed intrinsic sympathomimetic activity. Thus, small intravenous doses of 0.25 to $2 \mathrm{mg}$. $/ \mathrm{Kg}$. administered to the anesthetized dog resulted in tachycardia, a positive inotropic effect, and a slight hypotensive action; events which are qualitatively similar to those of isoproterenol.

In 1962, pronethalol (1-[2-naphthyl]-2 isopropylaminoethanol hydrochloride; Alderlin, Nethalide), another isoproterenol analog with beta-receptor blocking activity, was introduced by Black and Stephenson. ${ }^{11}$ Pronethalol resembles DCI in its actions except that it possesses considerably less intrinsic sympathomimetic activity, and shows myocardial depressant activity only in concentrations approximately 10 times those required to produce beta-receptor blockade. Dornhorst and Robinson, ${ }^{30}$ Stock and Dale ${ }^{110}$ and Pilkington et al. ${ }^{{ }^{5}}$ reported on the clinical pharmacology of pronethalol, making it the first clinically useful beta-adrenergic receptor blocking agent. However, the report by Paget $^{81}$ indicating that pronethalol was capable of producing lymphosarcomas in mice led to its withdrawal from clinical use; with the almost simultaneous introduction of propranolol (1-isopropylamino-3-[1-naphthyloxy]-2-propanol hydrochloride; Inderal). Black and co-workers ${ }^{9}$ demonstrated propranolol to possess almost no intrinsic sympathomimetic activity and to be approximately ten times as potent as pronethalol with respect to beta-adrenergic receptor blocking activity. In addition, Tucker et al. ${ }^{116}$ reported that propranolol did not possess carcinogenic potential. In 1965, Black et al. ${ }^{10}$ published a detailed comparison of the pharmacological properties of pronethalol and propranolol. At about the same time that propranolol was introduced, Larson and Lish ${ }^{56}$ described a new group of beta-adrenergic blocking agents; the most outstanding member of the series being MJ1999, which was shown to be six times as potent as DCI as a beta-adrenergic blocking agent. Other compounds have been described as well, including analogs of methoxamine, ${ }^{16}$ INPEA, ${ }^{10,5} \mathrm{~K}_{0}{ }^{592,{ }^{32}}$ and a series of betareceptor blocking agents described by Corrodi et al. ${ }^{23}$ More recently several new beta-adrenergic receptor blocking agents have been introduced: $\mathrm{H}$ 56/28 (Aptin) which has been the subject of a comprehensive review, ${ }^{1}$ and ICI 50172 , an agent which has been reported to be highly selective with respect to producing blockade of cardiac beta-adrenergic receptors."

\section{Metabolic Effects of Adrenergic Stimulation and the Consequences of Beta-Adrenergic Receptor Blockade}

The administration of catecholamines to animals and man results in a variety of metabolic effects which include hepatic release of potassium ion; hepatic, cardiac and skeletal muscle glycogenolysis; elevation of blood lactic acid; and lipolysis of triglycerides in adipose tissuc.

The catecholamine-induced hyperkalemia is thought to be mediated via alpha-adrenergic receptor stimulation. It may be produced by epinephrine, norepinephrine but not by isoproterenol and may be prevented by previous administration of alpha-receptor blocking agents. ${ }^{i !}$ 


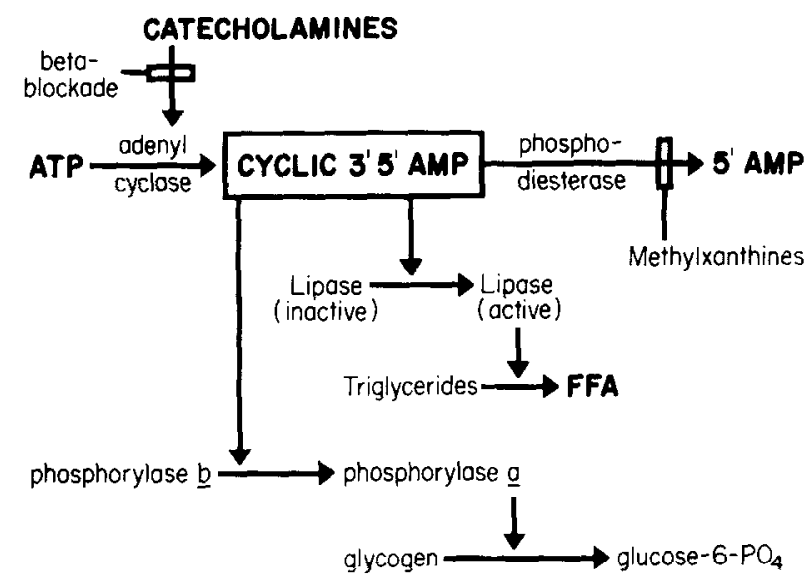

Fig. 2-Schematic representation of possible pathways of action of catecholamines upon carbohydrate and lipid metabolism and possible sites of action of bcta-adrenergic receptor blocking drugs and the methylxanthines.

The work of Sutherland ${ }^{112}$ has demonstrated that glycogenolysis is dependent upon the conversion of the enzyme phosphorylase $b$ to its active form, phosphorylase $a$, and that epinephrine resulted in activation of the enzyme. Subsequent studies ${ }^{91,92}$ established that the activation of phosphorylase in liver, skeletal and cardiac muscle was mediated via the action of cyclic $3^{\prime} 5^{\prime}$ adenosine monophosphate (cyclic $35^{\prime} \mathrm{AMP}$ ), and that the catecholamines are capable of increasing the rate of production of cyclic $35^{\prime}$ AMP in preparations from liver, skeletal muscle, cardiac muscle, adipose tissue, and probably in other tissues as well.113.114 The level of cyclic $3^{\prime} 5^{\wedge}$ AMP within the cells depends upon the relative activities of at least two enzymes, vir, adenyl cyclase, which catalyzes the conversion of adenosine triphosphate (ATP) to cyclic $35^{\prime}$ AMP, and a phosphodiesterase which catalyzes the breakdown of cyclic $3^{\prime} 5^{\prime}$ AMP to the adenosine monophosphate ( 5 ' AMP).

In addition to the alterations in carbohydrate metabolism, considerable evidence exists with respect to the ability of catecholamines to elevate plasma free fatty acids by increasing lipolysis of triglycerides in adipose tissue. Similar to the events which lead to glycogenolysis, cyclic $3^{\prime \prime} 5^{\wedge}$ AMP appears to play a prominant role in mediating the lipolytic action of the catecholamines. ${ }^{1,51}$ Studies by Klainer et al..$^{51}$ and Butcher ${ }^{17}$ have shown that catecholamines increase adenyl cyclase activity as well as the levels of cyclic $3^{\prime} 5^{\prime}$ AMP in adipose tissue. The scheme presented in Fig. 2 summarizes the metabolic sequence of events following adrenergic stimulation.

It is not possible, at present, to classify the adrenergic receptors which mediate the hepatic glycogenolytic effects of the catecholamines as alpha or beta on the basis of available evidence. Part of the difficulty arises from the observation that the relative potencies of various catecholamines in inducing hyperglycemia are quite different from their potencies in activating betareceptors of other tissues; and antagonism of the metabolic responses has not correlated well with either alpha or beta-blockade. Furthermore, the results 
are complicated by the existence of marked species differences. Thus, Mayer et al $^{6}{ }^{6}$ reported a prevention of the catecholamine-induced hyperglycemic response in the dog by prior administration of a beta-receptor blocking agent. This is in contrast to alpha-adrenergic blocking agents which others have reported to be ineffective. ${ }^{46,6 ;}$ Furthermore, the studies by Murad et al. ${ }^{i i}$ have shown that the accumulation of cyclic $3^{\prime} 5^{\prime}$ AMP following the addition of epinephrine in dog liver homogenates could be prevented by the beta-receptor blocking agent, DCI.

The results obtained in humans with respect to the blockade of catecholamine-induced hyperglycemia are in marked contrast to studies performed in the dog. Pilkington et al.," Muir et al. ${ }^{-{ }^{6 i}}$ and Hunninghake et al. ${ }^{19}$ have reported that beta-adrenergic receptor blockade failed to prevent or reduce the hyperglycemia associated with exogenous catecholamine administration or that associated with exercise. An unexplained observation is that reported by Hunninghake et $\mathrm{al}^{49}$ in which butoxamine administration resulted in a lowering of fasting plasma glucose levels in man, but did not prevent the catecholitmine-induced hyperglycemia in man. ${ }^{6.5}$ The inability to classify the hepatic glycogenolytic adrenergic receptor in man is further emphasized by the finding that isoproterenol, a specific beta-adrenergic receptor agonist, does not produce a hyperglycemia in $\operatorname{man}^{49}$ in contrast to its action in the dog." This observation agrees with those of Murad et al. with respect to the relative potencies of the catecholamines in clevating the levels of cyclic $33^{\prime} 5^{\prime}+M P$ in dog liver homogenate preparations and prevention of the response by the beta-blocking agent DCI. The available evidence suggests that catecholamineinduced hyperglycemia in the dog, but not in man, involves interaction with receptors which are, or resemble, beta-adrenergic receptors.

The stimulation of cyclic $35^{\prime} 5^{\prime}$ AMP, the activation of phosphorylase and glycogenolysis in dog and rat heart preparations are antagonized by betaadrenergic receptor blockade. ${ }^{1 \times 51,05,-i}$ Thus, glycogenolysis in myocardial tissue is classified as a beta-receptor mediated event.

The role of the sympathetic nervous system in fat deposition and mobilization $^{1: 1}$ as well as the ability of injected epinephrine to mobilize lipids ${ }^{6+1}, 1: 1$ have been adequately demonstrated. Epinephrine and norepinephrine elevate plasma free fatty acids in man and $\operatorname{dog}^{2 \pi+t i}$ and promote lipolysis in adipose tissue in vitro. ${ }^{12:}$ Isoproterenol, likewise, has been demonstrated to induce free fatty acid release in man." Finally, stimulation, with frequencies within the physiologic range, of sympathetic nerves innervating canine subcutaneous adipose tissue, promotes the rclease of frec-fatty acids." ${ }^{\text {mi }}$

The free-fatty acid mobilization following adrenergic stimulation is susceptible to blockade by various adrenergic blocking agents. Results obtained with alpha-receptor blocking agents are not in full agreement. Ergotamine, Dibenamine, phenoxybenzamine and phentolamine have been reported to produce cffective blockade of lipid mobilization in rat, dog, and man ${ }^{13,+6,1(1,1: 10}$ whereas others have not observed similar results with these blocking agents. ${ }^{5-1}$ Fain et al. ${ }^{3 i}$ have reported that phenoxybenzamine had little inhibitory effect on the lipolytic action of catecholamines in fat cells but reduced that of growth hormone and glucocorticoid.:" It has been reported that both phenoxybenza- 
mine $^{120}$ and butoxamine ${ }^{100}$ reducc fatty acid mobilization in diabctes, and their effects are taken as proof of the involvement of the adrenergic nervous system in diabetic ketosis. However, these effects could probably have been due to the antagonism of the lipolytic effect of growth hormone and glucocorticoid. ${ }^{36}$

The bcta-adrenergic blocking agent, DCI, has been shown to block the effect of catecholamines in fatty acid mobilization in $\operatorname{dogs}^{66}$ and to prevent catecholamine-induced lipolysis in incubated adipose tissue. ${ }^{58}$ Propranolol, likewise, has been shown to block the lipolytic action of epinephrine, ${ }^{36}$ but did not block the lipolytic activity of growth hormone and dexamethasone ${ }^{3 i}$ or that of ACTII. ${ }^{36}$ Similar results have been reported by Stock and Westermann $^{111}$ using the beta-receptor blocking agent $\mathrm{K}_{0} 092$.

There are at least three different mechanisms for activation of lipolysis in fat cells: the interaction of catecholamines with a beta-adrenergic receptor which results in a rapid activation of a triglyceride lipase (via cyclic $3^{\prime} 5^{\prime}$ AMP). ACTH may produce a similar effect, but does not react with the catecholamine receptor site. The stimulation of lipolysis by growth hormone and a glucocorticoid appears to be mediated through a mechanism which involves RNA and protein synthesis and thus exhibits a lag phase of several hours. ${ }^{36}$ It is perhaps the interplay of all the above mentioned factors which permits the homeostatic control of lipid mobilization. Thus, more than one site of drug-induced blockade can conceivably exist. Comparison of the effects of various drugs indicates that some drugs which have been described as adrenergic antagonists are actually nonspecific inhibitors of lipolysis. Thus, alpha blocking drugs preferentially block the lipolytic action of growth hormone and glucocorticoids. Phentolamine will block the lipolytic action of epinephrine, but proporanolol, a beta-blocking drug, is 300 times more effective as well as being a specific competitive antagonist of catecholamineinduced lipolysis, with little effect on the lipolysis induced by other agents. ${ }^{3 i j}$ Fain ${ }^{36}$ has suggested that the receptor for catecholamines in isolated fat cells should be classified as a beta-adrenergic receptor on the basis of the high specificity and potency of beta-adrenergic blocking drugs as antagonists of catecholamine-induced lipolysis and secondly, the order of potency of the lipolytic effects of catecholamines, e.g., isoproterenol>epinephrine and norepinephrine.

\section{Effects of Beta-Adrenergic Receptor Blockade upon the Cardiovascular System}

\section{Hemodynamics}

The blockade of cardiac beta-adrenergic receptors, as first demonstrated by Moran and Perkins ${ }^{74}$ with DCI, prevents or reduces the usual positive inotropic and chronotropic actions resulting from either catecholamine administration or cardiac sympathetic nerve stimulation. The depressor response to isoproterenol was likewise reduced or abolished, while the pressor responses to epinephrine and norepinephrine were unaffected or potentiated. Subsequently, Black and Stephenson ${ }^{11}$ reported similar effects with pronethalol. Unfortunately, both DCI and pronethalol possessed significant intrinsic sympatho- 
mimetic actions ${ }^{29,74}$ in the anesthetized dog, making it difficult to assess the true significance of myocardial beta-receptor blockade. The introduction of propranolol $^{9}$ provided the first beta-receptor antagonist devoid of intrinsic sympathomimetic activity. In anesthetized dogs with intact cardiac innervation and intrinsic sympathetic tone, propranolol has been reported to decrease the resting heart rate, myocardial contractile force and blood pressure, after doses which produce beta-receptor blockade. ${ }^{i s}$ The effects of given doses of isoproterenol $(0.004$ to $312.5 \mu \mathrm{g}$. $/ \mathrm{Kg}$. $)$ on systemic arterial pressure and myocardial contractile force were reduced or completely blocked by progressively increasing doses of propranolol; the larger doses of isoproterenol being able to surmount the blocking effect of propranolol on myocardial contractile force. ${ }^{88}$ Flacke et al.$^{38}$ have reported that propranolol, in doses up to $1 \mathrm{mg} . / \mathrm{Kg}$, did not exert a negative inotropic or negative chronotropic effect in anesthetized dogs in which autonomic tone had been eliminated by sympathetic and parasympathetic blockade. Arterial pressure, aortic blood flow and atrial pressures were unaltered ${ }^{38}$ However, a dose of $3 \mathrm{myg} / \mathrm{Kg}$. of propranolol did cause a decrease in heart rate, contractile force and blood pressure, and increased left atrial pressure. Flacke et al. ${ }^{38}$ concluded that in the absence of endogenous neurogenic tone, propranolol has no direct depressant effect upon cardiovascular function in doses which cause beta-receptor blockade.

The effect of beta-adrenergic receptor blockade (propranolol; Kö 592) on the racing performance of normal greyhounds and greyhounds with chronic extrinsic cardiac denervation was reported by Donald et al. ${ }^{28}$ Beta-receptor blockade resulted in a slight increase in racing time in the normal animal with only a slight reduction in the maximal heart rate. In the animals with chronically denervated hearts, racing time was prolonged, cardiac acceleration was severely limited, and the animals finished running in a state of collapse. Thus, maximal performance is dependent upon the cardiostimulant action of both sympathetic nerves and circulating catecholamines. Analogous studies in man ${ }^{3:-}$ were carried out to assess the effects of beta-adrenergic blockade on the circulating responses to treadmill exercise in normal subjects and subjects with heart disease. In normal subjects propranolol produced a fall in the endurance time to maximal exercise, which was 40 per cent less on the average than the control. This was associated with decreases in cardiac output ( 22 per cent), mean arterial pressure ( 15 per cent), left ventricular minute work ( 34 per cent), and maximal oxygen uptake (6 per cent). Increases in the arteriovenous oxygen difference (12 per cent) and the central venous pressure $(2.8 \mathrm{~mm} . \mathrm{Hg}$ ) were noted after beta-receptor blockade. Similar results were obtained in patients with heart disease who were made to exercise maximally. Under conditions of sub-maximal exercise, propranolol produced similar circulatory responses with the exception that oxygen uptake was not altered. The decrease in eardiac output ( 18 per cent below control) was compensated for by an increase in the arteriovenous oxygen difference.

The response of heart size to exercise measured before and after betireceptor blockade has shown an increase in ventricular end-diastolic dimensions, whereas exercise in the unblocked, normal subject results in a decrease in ventricular dimensions. ${ }^{19,1066}$ Recent studies by Robin et al. ${ }^{95}$ have demon- 
strated the effects of propranolol upon the hemodynamic parameters in patients with and without coronary artery disease. Intravenous propranolol produced a fall in velocity of shortening of myocardial fibers, heart rate, $\mathrm{dp} / \mathrm{dt}$, stroke index and left ventricular minute work. However, there was a concomitant increase in left ventricular end-diastolic pressure which was greater in patients with arteriosclerotic heart disease. In both groups, propranolol resulted in a decrease in mean systolic ejection rate and in left ventricular minute work. Sowton and Hamer ${ }^{14}$ likewise demonstrated that beta-adrenergic receptor blockade prolonged the systolic ejection period at rest and during exercise and increased ventricular dimensions during exercise. ${ }^{19.1 \ldots ;}$ Both al terations tend to increase myocardial oxygen consumption by prolonging the time during which the ventricle maintains tension and by increasing the ventricular wall tension necessary to maintain a given pressure. However, the decrease in the velocity of fiber shortening and the extent of fiber shortening produced by beta-adrenergic blockade ${ }^{\left(n, n_{11}\right.}$ coupled with the negative chronotropic response and a reduction in arterial pressure ${ }^{35,10 x}$ should reduce myocardial oxygen demands. Sonnenblick et al. ${ }^{117}$ using the maximum and mean rates of ventricular ejection and the rate of left ventricular pressure rise ( $\mathrm{dp} / \mathrm{dt}$ ) as determinants of myocardial fiber shortening, demonstrated a direct correlation between myocardial oxygen consumption and velocity of contraction. Thus, following propranolol the increased myocardial oxygen demand is offset by those factors which tend to reduce myocardial oxygen consumption. The net effect is a balance between these diverse effects in which myocardial oxygen consumption may increase or decrease. A number of studies ${ }^{21,6 i, 124 i}$ have demonstrated a reduction in myocardial oxygen consumption following beta-adrenergic receptor blockade. In a recent clinical study, Lewis and Brinkii have evaluated the hemodynamic and cardiac metabolic effects of propranolol in patients with ischemic heart discase. The results of this study indicated that $10 \mathrm{mg}$. of propranolol intravenously produced a significant reduction in heart rate, left ventricular isometric tension development ( $\mathrm{dp} / \mathrm{dt}$ ), whereas left ventricular end-diastolic pressure rose; findings which have been stressed in previous clinical and physiologic studies. ${ }^{3 \ldots}, 1 ; 1$ Myocardial oxygen consumption decreased in 4 patients after propranolol, but an increase was noted in 4 additional patients-results which might possibly have been attributed to the net balance between the opposing factors which determine whether myocardial oxygen consumption is reduced or increased.".:

The hemodynamic alterations of the coronary vascular bed resulting from catecholamines and the role of adrenergic receptors in the regulation of myocardial blood flow have been of interest. Some studies have indicated that epinephrine or norepinephrine are solely coronary vasodilators, ${ }^{12.130}$ while

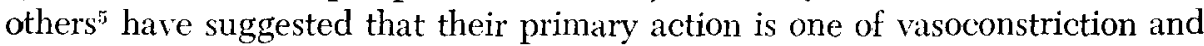
that the increased coronary flow usually observed is secondary to metabolic changes associated with myocardial stimulation. Isolated smooth muscle preparations from coronary arteries have been shown to possess both alpha and beta receptor activity, with a clear difference between the ratio of alpha to beta receptors in small coronary arteries and that in large coronary arteries. ${ }^{12.13 n}$ Strips from small coronary arterics of humans, rabbits, dog, and 
monkeys show predominantly or exclusively beta-adrenergic activity, whercas responses of large coronary arteries differ in that alpha receptor activity associated with smooth muscle contraction predominates. The responses could be prevented by appropriate receptor blocking agents. Folle and Aviado ${ }^{39}$ showed in anesthetized dogs that a beta-receptor blocking agent abolished the coronary vasodilatation produced in response to systemic anoxemia. Klocke and associates ${ }^{52}$ observed coronary vasodilatation after the intracoronary injection of isoproterenol; a response which could be prevented by prior betaadrenergic receptor blockade. Parratt and Grayson ${ }^{33}$ have suggested that the alpha-receptor mediated vasoconstriction following blockade of beta-adrenergic receptors leads to an increase in coronary vascular resistance and a decrease in coronary blood flow. The results of other studies ${ }^{124}$ suggest that the increase in coronary vascular resistance which occurs following propranolol is not related entirely to specific beta-adrenergic receptor blockade. The major part of the increased resistance appears to be associated with the reduced myocardial energy requirements resulting from cardiac slowing and reduction in the rate of tension development.

2. Pharmacologic Basis for the Use of Beta-Adrenergic Receptor Blocking Agents in the Management of Idiopathic Hypertrophic Subaortic Stenosis and Tetralogy of Fallot

Drugs which exert a positive inotropic effect-e.g. digitalis, isoproterenolare known to increase the systolic pressure gradient across the outflow tract of the left ventricle, and decrease the effective size of the outflow orifice in patients with IHSS. ${ }^{13.14}$ Similar effects occur with exercise or emotional excitation. In addition, exercise-induced angina pectoris is a distressing symptom in many patients with IHSS due to the increase in myocardial oxygen consumption. During exercise, the enhanced adrenergic drive increases left ventricular work by increasing its output and by increasing obstruction to outflow. ${ }^{1.5}$ Studies of tissue resected at operation from the outflow tract of the left ventricle of patients with obstructive cardiomyopathies have demonstrated proliferation of sympathetic nerve fibers in the abnormal muscle as well as an increased content of norepinephrine. ${ }^{8 t}$ This lends further significance to the role of the sympathetic nervous system in the physiologic derangements in patients with IHSS. Thus, in IHSS beta-adrenergic receptor blocking agents would appear to be useful in modifying or preventing the pathophysiologic effects of augmented sympathetic nerve discharge. Studies by Goodwin et al. ${ }^{17}$ and Harrison et al. ${ }^{45}$ showed that pronethalol had little effect upon gradients across the left ventricular outflow tract in patients at rest. However, gradients enhanced by exercise or by isoproterenol infusions were reduced by pronethalol along with a return toward normal of left ventricular $\mathrm{dp} / \mathrm{dt}^{4+} \mathrm{Sub}$ sequent studies with propranolol have shown that 10 of 13 patients with IHSS were subjectively improved, effort tolerance improved in 7 of 9 patients, and syncope was prevented in 5 of 6 patients. ${ }^{20}$ All patients had an ejection type of systolic murmur which decreased in 9 of the 13 . Intensification of the murmur after exercise no longer occurred in 7 of 13, all of whom received 5 to $20 \mathrm{mg}$. of propranolol orally three times daily." The amelioration of angina 
pectoris in patients with IHSS following propranolol ( 80 to $480 \mathrm{mg}$. daily) has been reported by Cohen and Braunwald."

The mechanisms by which propranolol benefits the patients with IHSS may be: the bradycardia following beta-adrenergic blockade may increase cardiac volume which may relieve obstruction; the reduction in cardiac work may prevent angina pectoris; beta-adrencrgic blockade prevents the adrenergically mediated augmentation of ventricular contraction ( $\mathrm{dp} / \mathrm{dt}$ ) associated with exercise, thus decreasing obstruction to the left ventricular outflow tract, and decreasing the left ventricular-aortic gradient.

In Fallot's tetralogy the magnitude of the right to left shunt is dependent on the relative resistances to blood flow through the aorta (systemic vascular resistance) and the pulmonary artery (narrow muscular right ventricular outflow tract). Augmentation of cardiac contractile force, as with exercise, further narrows the right ventricular outflow tract leading to an intensification of the cyanosis and possible syncope. ${ }^{128}$ The right to left shunt in patients with Fallot's tetralogy may be considerably increased by drugs such as norepinephrine, reproducing the clinical picture of the hypercyanotic spells ${ }^{50}$; an observation which would suggest that the right outflow tract obstruction is increased by enhancement of sympathetic nerve activity. That this may be the case is supported by the finding that beta-adrenergic receptor blockade will reduce the fall in arterial saturation which occurs during exercise in patients with the tetralogy. ${ }^{47}$ Thus, beta-adrenergic receptor blockade, by preventing the augmented ventricular response to sympathetic nerve stimulation, decreases right ventricular outflow tract obstruction. In addition, the increase in peripheral arterial resistance leads to a reduction in the right to left shunt and an increase in pulmonary blood flow. ${ }^{33}$

Cummings and $\mathrm{Carr}^{24}$ reported significant improvement in 3 infants having hypoxic spells treated with propranolol; these results were confirmed by Shak and Kidd. ${ }^{102}$ Both exercise and isoproterenol infusion result in a drop in arterial oxygen saturation and an increase in the right to left shunt in patients with tetralogy; events which could be abolished or reduced in magnitude by previous intravenous infusion of propranolol in a dose of $0.2 \mathrm{mg} . / \mathrm{Kg}$. Propranolol, in doses which abolished the response to isoproterenol, produced a rise (5-10 per cent) in resting arterial oxygen saturation. Although propranolol administered orally (1-4 mg. every 8 hours) was reported to be ineffective, ${ }^{97}$ there seems little doubt that intravenous propranolol has an important part to play in the management of infants with Fallot's tetralogy whose condition deteriorates rapidly because of syncopal attacks, if only to allow a longer time in which to prepare them for surgical treatment.

\section{Antiarrhythmic Effects}

a. Catecholamine-induced arrhythmias. As proposed by Ahlquist, ${ }^{2,3}$ there are two types of adrenotropic receptors in the mammalian heart, the betareceptors which subserve the inotropic and chronotropic responses to adrenergic stimuli, and the alpha-receptors which mediate the ectopic excitation induced by sympathetic stimuli. Evidence for the function of the alpha-receptor in the myocardium was based upon the observation that Dibenamine (an 
alpha-adrenergic receptor blocking agent) prevents arrhythmias rcsulting from the combined administration of a hydrocarbon anesthetic agent and epinephrine. However, this concept was challenged by Moe et al. ${ }^{i 1}$ who demonstrated that the protection provided by Dibenamine against the hydrocarbon-epinephrine arrhythmia was due to the annulment of the vasopressor effect of epinephrine by the alpha-receptor blocking agent and that mechanical elevation of the blood pressure could restore the arrhythmogenic action of epinephrine. ${ }^{i 1}$ Following the introduction of DCI, several investigators compared the effectiveness of alpha- and beta-receptor blocking agents in antagonizing catecholamine-induced arrhythmias. ${ }^{41.72,73}$ Infusion of norepinephrine during the application of successive stimuli to the right and left ventricles produced ventricular arrhythmias ranging from extrasystoles to ventricular fibrillation; ${ }^{41}$ arrhythmias which could be prevented by beta-adrenergic receptor blockade with DCI, but not by alpha-receptor blockade. Moore and Swaini: and Moran et al. ${ }^{i 3}$ observed that ventricular fibrillation produced by the combined use of the substituted propiophenone, U-0882, and catecholamines was antagonized by beta-receptor blockade. DCI also inhibited the epinephrine and norepinephrine-induced ventricular arrhythmias in conscious dogs following coronary artery ligation, but did not abolish the spontaneous ventricular arrhythmias 24 hours after myocardial infarction..$^{i 3}$ Subsequent studies with pronethalol and propranolol supported the previous observations in showing that catecholamine-induced arrhythmias could be antagonized by specific beta-receptor blockade ${ }^{59,62,63}$ Studies in the experimental animal have shown the beta-adrenergic blocking agents to be ineffective in preventing or terminating the spontaneously developing arrhythmias following acute myocardial infarction. ${ }^{59,73}$ However, beta-adrenergic receptor blocking drugs are capable of preventing catecholamine-induced arrhythmias in animals previously subjected to acute myocardial infarction. ${ }^{5,63}$ The dextro-isomers of pronethalol and propranolol, which lack beta-receptor blocking properties, were unable to prevent catecholamine-induced rhythm disturbances, ${ }^{59,63}$ therefore demonstrating the specificity of the antiarrhythmic effect which is mediated via blockade of cardiac beta-adrenergic receptors. To date, all known cardiac beta-adrenergic receptor blocking agents are able to produce this specific antiarrhythmic effect with the only difference being quantitative in nature.

b. Atrioventricular conduction and beta-adrenergic receptor blockade. It is well known that the sympathetic nervous system has an important role in regulating both the frequency of cardiac-impulse generation and the functional refractory period of atrioventricular conduction. ${ }^{.3}$ When normal atrioventricular conduction takes place, the ventricular contraction rate is limited by the atrioventricular nodal system, which has been shown in experimental animals to have a longer effective refractory period than atrial or ventricular tissue. ${ }^{70}$ Sympathetic denervation, $;, 119$ depletion of cardiac norepinephrine stores by reserpine, ${ }^{75 i}$ and beta-adrenergic receptor blockade by propranolol ${ }^{98,119}$ have been shown to increase the atrioventricular functional refractory period and to slow atrioventricular conduction. The effect of propranolol on ventricular rate during supraventricular arrhythmias is not usually associated with an alteration in atrial rate or rhythm. Rather it results primarily from a prolongation of the 
refractory period of the atrioventricular-conducting system which is controlled to a large extent by the activity of the adrenergic nervous system and, as demonstrated in the experimental animal, may be markedly prolonged by beta-adrenergic receptor blockade." Furthermore, one may expect the action of propranolol upon atrioventricular conduction to be additive to that of digitalis, ${ }^{99}$ and provides a means of further decreasing the ventricular rate.

c. Digitalis-induced arrhythmias. As has been discussed previously, the capacity to antagonize catecholamine-induced arrhythmias with beta-receptor blocking drugs is dependent upon specific beta-adrenergic receptor blockade and is a property possessed by all drugs belonging to the class of betaadrenergic receptor blocking compounds. That beta-adrenergic receptor blocking agents possess antiarrhythmic properties independent of their ability to induce specific receptor blockade was demonstrated initially with dichloroisoproterenol, which was shown to antagonize digitalis-induced arrhythmias in the experimental animal. ${ }^{61}$ The non-specific anti-arrhythmic property of the beta-adrenergic receptor blocking agents was cstablished more firmly by the demonstration that the dextro-rotatory isomers of pronethalol and propranolol, which do not produce beta-receptor blockade, were able to antagonize experimentally-induced digitalis arrhythmias. ${ }^{9.63}$ It is of further importance to note that not all beta-adrenergic receptor blocking agents are capable of suppressing digitalis-induced arrhythmias although they antagonize catecholamine-induced rhythm disturbances, ${ }^{103-10 ;}$-a finding which emphasizes the nonspecific antiarrhythmic action of propranolol. Thus, the beta-adrenergic blocking drugs may be classified into two groups based upon the type of rhythm disturbances which they suppress: those which antagonize catecholamine as well as digitalis-induced arrhythmias, and those which specifically suppress catecholamine-induced arrhythmias. In the former group are such agents as: dichloroisoproterenol, pronethalol, propranolol, and H56/28. ${ }^{1,54 t ; 1-63}$ The latter group consists of INPEA and MJ 1999. ${ }^{103-10: 3}$

The effects of several beta-adrenergic receptor blocking agents upon myocardial transmembranc action potcntials have becn studied in an attempt to elucidate the mechanism of their nonspecific antiarrhythmic properties. Initial studies by Sekiya and Vaughan Williams ${ }^{13}$ revealed that quinidine and pronethalol raised the electrical threshold and reduced the conduction velocity and the maximum frequency at which atria would follow a stimulus. Both quinidine and pronethalol affected intraccllular action potentials in the same way, causing little change in the resting potential or duration of the action potential, but reducing the overshoot potential and slowing the rate of rise of the action potential. Subsequent studies with propranolol ${ }^{118}$ provided similar observations with respect to alterations in the transmembrane action potential and as with the previous agents suggested a mechanism which involved inhibition of a sodium-ion carrier system. More recently, Davis and Temte ${ }^{26}$ have studied the effects of propranolol on the transmembrane potentials of single ventricular muscle fibers and Purkinje fibers and the effect of propranolol on the response of Purkinje fibers to epinephrine. Processes involved in depolarization as well as those associated with repolarization were affected. Decreases in velocity of depolarization and in magnitude of overshoot and an 
impairment in ability to respond to rapid stimulation occurred in both fiber types studied. Significant changes in the repolarization process were limited to Purkinje fibers. Doses of propranolol that greatly accelerate repolarization of Purkinje fibers had relatively little effect on this feature of ventricular muscle fibers in the same preparation. Propranolol is not unique among antiarrhythmic agents with respect to its action on shortening the refractory period of Purkinje fibers. Diphenylhydantoin has been shown to produce a similar effect.

As shown by Davis and Temte, ${ }^{21}$ propranolol prevents local responses and decremental conduction-actions which are perhaps more significant in accounting for its antiarrhythmic action. The results of these studies indicated that propranolol produces changes in the transmembrane potential that are independent of an action on beta-receptors. Furthermore, propranolol was shown to prevent the increase in diastolic depolarization in Purkinje tissue caused by epinephrine; an action which may account for the ability of beta-receptor blocking agents to prevent epinephrine-induced arrhythmias. On the basis of electrophysiological studies, it is possible to speculate upon the possible mechanisms inirolved in the "specific" and "nonspecific" antiarrhythmic properties of propranolol.

The most serious side effects of beta-adrenergic receptor blockade with propranolol in the management of digitalis arrhythmias are hypotension, bradycardia, the aggravation of cardiac failure, and ventricular standstill. Patients with moderately advanced cardiac disease and whose hearts are to a large extent dependent upon their adrenergic nervous system for circulatory support may experience acute congestive failure upon the administration of a betaadrenergic receptor blocking agent. This was first noted by Stock and Dale, ${ }^{10}$ who reported the aggravation or precipitation of heart failure following pronethalol and advised the cautious use of the drug in the presence of established or incipient heart failure. Impairment of cardiac function may be manifest not only in an inability to augment the cardiac output, but also in a diminished ability to excrete sodium, with resultant fluid accumulation and edema. $^{3 *}$ In patients with normal or only mildly impaired cardiac function, the only effect of propranolol will be to lower the cardiac output during exercise and to alter the diumal pattem of sodium excretion. As heart failure progresses in severity, the effects of withdrawing sympathetic stimulation of the myocardium become more impressive and may result in actual sodium retention. In a patient with severe heart failure, propranolol will intensify the clinical manifestations of heart failure through mechanisms other than sodium retention. Since the dextro-isomer of propranolol is devoid of betareceptor blocking activity, but still possesses antiarrhythmic activity against digitalis arrhythmias, ${ }^{6: 123}$ it might serve as a valuable therapeutic agent in instances where reduction in cardiac sympathetic tone would be disadvantageous.

The depressant effect of propranolol on the atrioventricular node, although responsible for many of its useful clinical effects, is also a potential hazard. In patients with pre-existing defects of atrioventricular conduction, complete heart block may be produced by beta-blockade. However, it is important 
to note that the myocardium will respond to mechanical or electrical stimuli following suppression of all pacemaker activity by propranolol."1:!

The bradycardia with the resultant decrease in cardiac output and the development of hypotension may be especially hazardous in patients dependent on the maintenance of a good heart rate for their cardiac function, particularly those with mitral and aortic incompetence. The blockade of beta-adrenergic receptors prevents the use of agents such as isoproterenol to augment the cardiac output, unless excessive dosages are administered to overcome the competitive receptor blockade, which may impose additional hazards upon an already critical patient. Recently, the hormone glucagon has been shown to be capable of augmenting cardiac contractility and heart rate in the presence of beta-adrenergic receptor blockade in the experimental animal ${ }^{12,60}$ and has been found to possess positive inotropic and chronotropic actions in man unaccompanied by the enhancement of ventricular irritability or increased peripheral resistance. ${ }^{52}$ Similar observations with glucagon have been made in patients developing acute congestive failure following the use of propranolol for the treatment of digitalis-induced arrhythmias. ${ }^{93}$ In addition, it has been observed that glucagon will reverse the depression of atrioventricular nodal transmission produced by propranolol in the experimental animal. ${ }^{125}$ The experimental data and the limited clinical experience with glucagon suggest that the hormone may provide hemodynamic bencfits in situations resulting from beta-adrenergic receptor blockade.

Although clinical data is lacking at present, beta-adrenergic receptor blockade, as indicated in the experimental animal, may be of value in the prevention of post-counter shock arrhythmias. The incidence of counter shock arrhythmias has been reported to be higher in digitalized than in nondigitalized patients. ${ }^{90}$ Studies in the experimental animal have indicated that dichloroisoproterenol, pronethalol, and propranolol reduced the duration of post-counter shock arrhythmias in both normal dogs and dogs given ouabain, ${ }^{115}$ an action which is believed to be the result of beta-adrenergic receptor blockade.

\section{Antihypertensive Action}

The use of beta-receptor blocking drugs in hypertensive therapy was reported by Prichard ${ }^{\mathrm{s}}$ and subsequently confirmed by Prichard and Gillam using propranolol. ${ }^{83}$ An appreciable hypotensive action was not seen following acute administration of pronethalol ${ }^{87}$ or of propranolol $^{4 s}$ in patients in normal cardiac rhythm. A slight hypotensive effect was observed after 1 to 2 weeks of oral administration ${ }^{87}$ with a more pronounced effect noted after $4 \mathrm{or}^{\mathrm{r}}$ more weeks of oral administration. Dosage of propranolol was commenced at $10 \mathrm{mg}$. four times daily, and increased by increments of $10 \mathrm{mg}$. each dose each week, $20 \mathrm{mg}$. increments being made when higher dose ranges were reached.

The hypotensive effect of beta-receptor blockade appears to result from a decrease in cardiac output. Furthermore, beta-receptor blockade would prevent the cardiac component of various stimuli responsible for transient rises in blood pressure. 
Postural hypotension was not a feature nor was exercise hypotension observed in patients receiving oral propranolol. ${ }^{89}$ Its mode of action is different from most commonly employed antihypertensive agents which act primarily by reducing peripheral resistance, and the full hypotensive effect is not usually seen for several weeks after the start of therapy. In discussing the possible mechanisms for the antihypertensive action of propranolol it is interesting that Frolich and Page ${ }^{40}$ have suggested that they observed in their patients, "a modification of behavior, best described as a tranquilizing effect." Thus, in addition to a hemodynamic component there may be a more central one produced by these drugs. A centrally mediated hypotensive action for propranolol has been demonstrated in the experimental animal. ${ }^{109}$

\section{Miscellaneous Studies}

a. Parkinsonian tremor. The beta-receptor blocking agents pronethalol and propranolol have been reported to abolish the increase in tremor of patients with Parkinson's disease during infusions of epinephrine. ${ }^{80}$ In a double blind crossover trial involving 18 patients, the oral administration of propranolol (30 mg. three times daily for a week) was reported to have produced a significant reduction in the tremor. However, Vas, ${ }^{117}$ employing intravenous propranolol (10 mg.), was unable to demonstrate a significant reduction in recorded tremors.

b. Ventilatory function and bronchial asthma. McNeill ${ }^{68}$ has reported on side effects of beta-receptor blockade in asthmatics. He measured the 1 second force expiratory volume (F.E.V.1 ) before and after intravenous propranolol (5-10 mg.) and noted a pronounced fall in 4 of 10 patients. By using sensitive, body plethysmographic methods, airway narrowing has also been observed in normal subjects. ${ }^{69}$ Similar results in asthmatic patients have been reported by Deumer ${ }^{i}$ who administered propranolol in the form of an aerosol. Twentyone of 25 patients who inhaled propranolol showed a sudden and pronounced fall in ventilatory function. Of interest was the observation that the dextroisomer of propranolol (Dexinderal) did not alter the $F_{E V}$ in asthmatic patients; ${ }^{69}$ an observation which emphasizes the role of the beta-adrenergic receptor in the control of airway resistance. The bronchospasm produced by propranolol in asthmatics is the result of beta-receptor blockade which leaves the parasympathetic system relatively unopposed or may increase the sensitivity of the bronchial smooth muscle to either endogenous or exogenous stimuli as a result of the relative inability of the smooth muscle to respond to endogenous beta-adrenergic stimulation.

Aminophylline is a suitable bronchodilator when a wheeze or a frank attack of asthma develops in a patient receiving propranolol. ${ }^{69}$

These results suggest that beta-adrenergic blocking drugs should be used with caution in asthmatics. Furthermore, the dextro-isomers of beta-receptor blocking agents may be of value in certain clinical situations involving asthmatic patients.

\section{ACKNOWLEDGMENTS}

The authors want to express their thanks to Mrs. Gail Williams for typing of the manuscript and Mrs. Jeanne Brown for preparation of the hibliography. 


\section{REFERENCES}

1. Ablad, B., Brogard, M., and Ek, L.: Pharmacological properties of H56/28-a $\beta$ adrenergic receptor antagonist. Acta Pharmacol. et Toxicol. 25: (Suppl. 2) 9, 1967.

2. Ahlquist, R. P.: Study of the adrenotropic receptors. Amer. J. Physiol. 153:586, 1948.

3. Ahlquist, R. P.: In: Drill, V. A. (Ed.): Pharmacology in Medicine, 2nd ed. New York, McGraw-Hill, 1958.

4. Ariens, E. J.: The structure activity relationships of beta-adrenergic drugs and beta-adrenergic blocking drugs. Ann. N. Y. Acad. Sci. 139:606, 1967.

5. Berne, R. M.: Effect of epinephrine and norepinephrine on coronary circulation. Circulation Res. 6:644, 1958.

6. Beumer, H. M.: Inhalation of $\beta$-adrenergic blockers by asthmatics. Lancet 2 : $993,1967$.

7. Biel, J. H. and Lum, B. K. B.: The $\beta$-adrenergic blocking agents; pharmacology and structure activity relationships. In: Jucker, E. (Ed.): Progress in Drug Research. Basel, Birklauser Verlag, 1966, 604 pp.

8. Bigger, J. T., Jr., Bassett, A. L., and Hoffman, B. F.: Electrophysiological effects of diphenylhydantoin on canine Purkinje fibers. Circ. Res. 22:221, 1968.

9. Black, J. W., Crowther, A. F., Shanks, R. G., Smith, L. H., and Dornhorst, A. C.: New adrenergic beta-receptor antagonist. Lancet 1:1080, 1961.

10. Black, J. W., Duncan, W. A. M., and Sharks, R. G.: Comparison of some properties of pronethalol and propranolol. Brit. J. Phatmacol. 25:577, 1965.

11. Black, J. W., and Stephenson, J. S.: Phamnacology of a new adrenergic beta-receptor blocking compound (nethalide). Lancet 2:311, 1962 .

12. Bohr, D. F.: Adrenergic receptors in corimary arteries. Ann. N. Y. Acad. Sci. 139:799, 1967.

I3. Braunwald, E., Brockenbrough, E. C., and Frye, R. L.: Studies on digitalis. V. Comparison of the effects of ouabain on left ventricular dynamics in valvular aortic stenosis and hypertrophic subaortic stenosis. Circulation 26:166, 1962.

14. Braunwald, E. and Ebert, P. A.: Hemodynamic alterations in idiopathic hypertrophic subaortic stenosis induced by sympathonimetic drugs. Amer. J. Cardiol. $10: 489,1962$.

L5. Braunwald, E., Lambrew, C. T., Rockoff, S. D., Ross, J., Jr., and Morrow, A. G.: Idiopathic hypertrophic subaortic stenosis: 1. Description of the disease based upon an analysis of 64 patients. Circulation 30 (Suppl. IV): IV-3, 1964.

16. Burns, I. J., Salvador, R. A., and Lemburger, L.: Metabolic blockade by methoxamine and its analogs. Ann. N. Y. Acad. Sci. 139:8:33, 1967.

17. Butcher, R. W. K.: Cyclic 3' 5'-AMP and the lipolytic effects of hormones on adipose tissue. Pharmacol. Rev. 18:237, 1966.

18. Butcher, R. W., Ho, R. J, Meng, $H$. C., and Sutherland, E. W.: Adenosine $3^{\prime} 5^{\prime}-$ monophosphate in biological materials. II. The measurement of adenosine $3^{\prime} 5^{\prime}$-monophosphate in tissues and the role of the cyclic nucleotide in the lipolytic response of fat to epinephrinc. J. Biol, Chem. 240: $4515,1965$.

19. Chamberlain, D. A.: Effects of betaadrenergic blockade on heart size. Amer. J. Cardiol. 18:321, 1966.

20. Cherian, G., Brockington, J. F., Shah, P. M., Oakley, C. M., and Goodwin, J. F.: Beta-adrenergic blockade in hypertrophic obstructive cardiomyopathy. Brit. Med. J. $1: 895,1966$.

21. Clancy, R. L., Graham, T. P., Jr., and Gilmore, I. P.: Inotropic augmentations of myocardial oxygen consumption. Amer. J. Physiol. 212: 1055, 1967.

22. Cohen, L. S, and Braunwald, E.: Amelioration of angina pectoris in ideopathic hypertrophic subaortic stenosis with betaadrenergic blockade. Circulation 35:847, 1967.

23. Corrodi, H., Persson, H., Carlsson, A., and Roberts, J.: A new series of substances which block the adrenergic beta-receptors. J. Med. Chem. 6:751, 1963.

24. Cummings, G. R., and Carr, W.: Relicf of dyspneic attacks in Fallot's tetralogy with propranolol. Lancet 1:519, 1966.

25. Dale, H. H.: On some physiological actions of ergot. J. Physiol. 34:163, 1906.

26. Davis, L. D., and Temte, J. V.: Effects of propranolol in the transmembrane potential of ventricular muscle and Purkinje fibers of the dog. Circ. Res. 22:661, 1968.

27. Dole, V. P.: A relation between nonesterified fatty acids in plasma and the me- 
tabolism of glueose. J. Clin. Invest. 35:150, 1956 .

28. Donald, D. E., Ferguson, D. A., and Milburn, S. E.: Effect of beta-adrenergic receptor blockade on racing performance of greyhounds with normal and denervated hearts. Circ. Res. 22:127, 1968.

29. Donald, D. E., Kvale, J. and Shepherd, J. T.: The effect of an adrenergic beta-receptor antagonist on the cardiovascular system of the dog. J. Pharmacol. Exp. Ther. 143:344, 1964.

30. Dormhorst, A. C., and Robinson, B. F.: Clinical pharmacology of a betti-adrenergic blocking agent. Lancet 2:314, 1962 .

31. Dunlop, D., and Shanks, R. G.: Selective blockade of adrenoceptive beta receptors in the heart. Br. J. Pharmacol. 32 : 201, 1968.

32. Engelhardt, A.: Methode zur auswertung von beta-adrenolytica am isolierten Herzorhof. Arch. Exp. Path. Pharmak. 250: $245,1965$.

33. Epstein, S. E., and Braunwald, E.: Beta-adrenergic receptor blocking drugs: mechanism of action and clinical applications. New Erig. I. Med. 275:1106, 1966.

34. Epstein, 5. E., and Braunwald, E.: Clinical and hemodynamic appraisal of beta-adrenergic blocking drugs. Ann. N. Y. Acild. Sci. 139:952, 1967.

35. Epstein, S., Robison, B. F., Kahler, R. L., and Braunwald, E.: Effects of betaadrenergic blockade on cardiac response to maximal and submaximal exercise in man. J. Clin. Invest. 44:1745, 1965.

36. Fain, J. N.: Adrenergic blockade of homone-induced lipolysis in isolated fat cells. Ann. N. Y. Acad. Sci. 139:879, 1967.

37. Fain, J. N., Galton, D. J. and Kovacev, V. P.: Effect of drugs on the lipolytic action of hormones in isolated fat cells. Moler. Pharnucol. 2:237, 1966.

38. Flacke. J. W., Osgood, P. F., and Bendixen, H, H.: Propranolol and isoproterenol in dogs deprived of sympathetic nerve activity. J. Pharmacol. Exp. Ther. 158: $519,1967$.

39. Folle, L. E., and Aviado, D. M.: Circliovascular effects of anoxia and the influence of a new beta-adrenergic receptor blocking drug. J. Pharmacol. Exp. Ther. 1.19:79, 1965.

10. Frohlich, E. D. and Page, I. H.: The clinical meaning of cardiovascular betaaclenergic receptors. Physiol. Phamacol.
Physicians 1:(11), 1, 1966.

41. Gilbert, J. L., Lang, G. and Brooks, C. McC.: Influence of sympathominetic pressor drugs on arrhythmias caused by multiple stimuli. Circ. Res. 4:417, 1959.

42. Glick, G., Parmley, W. W., Wechsler, A. S., and Somnenblick, E. H.: Glucagon: Its enhancement of cardiac perfomance in the cat and dog and persistence of its inotropic action despite beta-receptor blockade with proprinolol. Circ. Res. 22: $789,1968$.

43. Goodman, II. M. and Knobil, E.: Effect of adrenergic blocking agents on fatty acid mobilization during fasting. Proc. Soc. Exy. Biol. Med. 102:493, 1959.

44. Coodwin, J. L., Shah, P. M., Oakley, C. M., Cohen, J., Yipintsoi, T., and Pocock, W.: The clinical phamacology of hypertrophic obstructive cardiomyopathy. In: Wolstenholme, G. E. W. (Ed.): CIBA Foundation Symposium: Cardionyopathies. Boston, Mass., Little, Brown, 1964, pp. 189-213.

45. Harrison, D. C., Braunwald, E., Glick, C., Mason, D. T., Chidsey, C. A., and Ross, I., Jr.: Effects of beta-adrenergic blockade on the circulation with particular reference to observations in patients with hypertrophic subartic stenosis. Circulation 29:84, 1964.

46. Havel, R. I., and Goldfein, A.: Role of sympathetic nervous system in metabolism of tree fatty acid. J. Lipid Res. 1:102, 1959.

47. Honey, M., Chamberlain, D. A., and Howard, J.: Effect of beta-sympathetic blockade on arterial oxygen saturation in Fallot's tetralogy. Circulation 30:501, 1964 .

48. Hornbrook, K. R., and Brody, T. M.: The effect of catecholamines on muscle? glycogen and phosphorylase activity. J. Pharmacol. Exp. Ther. 140:295, 1963.

49. Hunninghake, D. B., Azarnoff, D. L., and Waxman, D.: Drug inhibition of catecholamine-induced metabolic effects in humans. Ann. N. Y. Acad. Sci. 139:971, 1967.

50. Johnson, A. M.: Norepinephrine and cyanotic attacks in Fallot's tetralogv. Brit. Heart I. 23:197, 1961.

51. Klainer, L. M., Chi, Y. M., Freidberg, S. L., Rall, T. W., and Sutherland, E. W.: Adenyl cyclase. IV. The effects of neurohormones on the formation of adenosine 3 , $5^{\prime}$ phosphate by preparations from brain and other tissues. J. Biol. Chen. 237:1239), 1962.

52. Klocke, f. J., Kaiser, (i. A, Ross, 
J., Jr., and Braunwald, E.: Intrinsic adrenergic vasodilator mechanism in the coronary vascular bed of the dog. Circ. Res. 16:376, 1965.

53. Krayer, O., Mandoki, J. J., and Mendez, C.: Studies on veratrum alkaloids XVI. The action of epinephrine and of veratramine on the functional refractory period of the auriculoventricular transmission in the heart-lung prcparation of the dog. J. Pharmacol. Exp. Ther. 103:412, 1951.

54. Kvam, D. C., Riggilo, D. A., and Lish, P. M.: Effect of sune new $\beta$-adrenergic blocking agents on certain metabolic responses to catecholamines J. Pharmacol. Exp. Ther. 149:183, 1965.

55. Langley, I. N.: On the reaction of cells and of nerve endings to certain poisons, chiefly as regards the reaction of striated muscle to nicotine and to curare. J. Physiol. 33:374, 1905.

56. Larson, A. A., and Lish, P. M.: A new bio-isostere: alkylsulphonamido-phenethanolamines. Nature (Lond.) 203:1283, 1964.

57. Lewis, C. M., and Brink, A. J.: Betaadrenergic blockade. Hemodynamics and myocardial energy metabolism in patients with ischemic heart disease. Amer. J. Cardiol. 21:846, 1968 .

58. Love, W. C., Carr, L., and Ashmore, $J .:$ Lipolysis in adipose tissue: effects of dl3,4-dichloroisoproterenol and related compounds. J. Pharmacol. Fxp. Ther. 140:287, 1963.

59. Lucchesi, B. R.: The effects of pronethalol and its dextro-isomer upon experimental cardiac arrhythmias. J. Pharmacol. Exp. Ther. 148:94, 1965.

60. Lucchesi, B. R.: Cardiac actions of glucagon. Circ. Res. 22:777, 1968.

61. Lucchesi, B. R., and Hardman, H. F.: Influence of dichloroisoproterenol (DCI) and related compounds upon ouabain and acethystrophanthidin induced cardiac arrhythmias. J. Pharmacol. Exp. Ther. 132: $372,1961$.

62. I,ucchesi, B. R., Whitsitt, L. S., and Brown, N. L.: Propranolol (Inderal) in experimentally-induced cardiac arrhythmias. Canad. J. Physiol. Pharmacol. 44:543, 1966.

63. Lucchesi, B. R., Whitsitt, L. S., and Stickney, J. L.: Antiarrhythmic effects of belu-adrenergic blocking agents. Ann. N. Y. Acad. Sci. 139:940, 1967.

64. MacKay, E. M.: Influence of adrenalectomy on liver fat as varied by diet and other factors. Amer. J. Physiol. 120:361, 1937.

65. Mayer, S. E., and Moran, N. C.: Relation between pharmacologic augmentation of cardiac contractile force and the activation of myocardial glycogen phosphorylase. J. Pharmacol. Exp. Ther. 129:271, 1960.

66. Mayer, S. E., Moran, N. C., and Fain, J.: Effect of adrenergic blocking agents on some metabolic actions of catecholamines. J. Pharmacol. Exp. Ther. 134:18, 1961.

67. McKenna, D. H., Corliss, R. J., Sialer, S., Zarnstorff, W. C., Crumpton, C. W., and Rowe, G. G.: Effect of propranolol in systemic and coronary hemodynamics at rest and during exercise. Circ. Res. 19:520, 1966.

68. McNeill, R. S.: Effect of a $\beta$-adrenergic-blocking agent, propranolol, on asthmatics. Lancet 2:1101, 1964.

69. McNeill, R. S., and Ingram, C. G.: Effect of propranolol on ventilatory function. Amer. J. Cardiol. 18:473, 1966.

70. Mendez, C., Gruhzit, C. C., and Moe, G. K.: Influence of cycle length upon refractory period of auricles, ventricles, and A-V node in the dog. Amer. J. Physiol. 184: 287, 1956.

71. Moe, G. K., Malton, S. D., Rennick, B. R., and Freyburger, W. A.: The role of arterial pressure in the induction of idioventricular rhythms under cyclopropane anesthesia. J. Pharmacol. Exp. Ther. 94:319, 1948.

72. Moore, J. I., and Swain, H. H.: Sensitization to ventricular fibrillation. I. Sensitization by a substituted propiophenone, $U$. 0882. I. Pharmacol. Exp. Ther. 128:243, 1960 .

73. Moran, N. C., Moore, J. I., Holcomb, A. K., and Mushet, G.: Antagonism of adrenergically-induced cardiac arrhythmias by dichloroisoproterenol. J. Pharmacol. Exp. Ther. 136:327, 1962.

74. Moran, N. C., and Perkins, M. E.: Adrenergic blockade of the mammalian heart by a dichloro analog of isoproterenol. J. Pharmacol. Exp. Ther. 124:223, 1958.

75. Morrow, D. H., Gaffney, T. E., and Braunwald, E.: Studies on digitalis VIII. Effects of autonomic innervation and of myocardial catecholamine stores upon the cardiac action of ouabain. J. Pharmacol. Exp. Ther. 140:236, 1963.

76. Muir, G. G., Chamberlain, D. A., and Pedoe, D. T.: Effects of $\beta$-sympathetic blockade on non-esterified fatty acid and carbohydrate metabolism at rest and during 
exercise. Lancet 2:930, 1964 .

77. Murad, F., Chi, Y. M., Rall, T. W., and Sutherland, E. W.: Adenyl cyclase, part III, The effect of catecholamines and choline esters on the formation of adenosine $3^{\prime}, 5^{\prime}-$ phosphate by preparations from cardiac muscle and liver. J. Biol. Chem. 237:1233, 1962.

78. Nakano, J., and Kusakari, T.: Effect of beta-adrenergic blockade on the cardiovascular dynanics. Amer. J. Physiol. 210: 833, 1966.

79. Brien, G. S., Murphy, Q. R., Jr., and Meek, W. J.: The effect of sympathomimetic amines on arterial plasma potassium and cardiac rhythm in anesthetized dogs. I. Pharmacol. Exp. Ther. 109:453, 1953.

80. Owen, D. A. L., and Marsden, C. D.: Elfect of adrenergic $\beta$-blockade on Parkinsonian tremor. Lancet 2:1259, 1965.

81. Paget, C: E.: Carcinogenic action of pronethalol. Brit. Med. J. 2:1266, 1963.

82. Parmley, W. W., Glick, G. and Sonnenblick, E. H.: Cardiovascular effects of glucagon in man. New Eng. J. Med. 279: $12,1968$.

8:3. Parratt, J. R., and Grayson, J.: Myocardial vascular reactivity after beta-adreungic blockade. Lancet. 1:338, 1966.

84. Pearse, A. G. E.: The histochemistry and electron microscopy of obstructive cardiomyopathy. In: Wolstenholme, G, E. W. (Ed.): CIBA Foundation Symposium: Cardiomyopathies. Boston, Mass., Little, Brown, 1964, pp. 132-164.

85. Pilkington, T. R. E., Lowe, R. D., Robinson, B. F., and Titterington, E.: Effect of adrenergic blockade on glucose and fatty acid mobilization in man. Lancet 2:316, 1962.

86. Powell, C. E., and Slater, I. H.: Blocking of inhibitory adrenergic receptors by a dichloro analog of isoproterenol. J. Phirumacol. Exp. Ther. 122:480, 1958.

87. Prichard, B. N. C.: Hypertensive action of pronethalol. Brit. Med. J. I:1227, 1964.

88. Prichard, B. N. C., and Gillam, P. M. $S .:$ 'The use of propranolol in the treatment of hypertension. Brit. Med. J. 2:725, 1964.

s9) Prichard, B. N. C., and Gillam, P. M. $S .:$ Propranolol in hypertension. Amer. J. Cardiol. 18:387, 1966.

90. Rabbino, M. D., Likoff, W., and Dreifus, L. S.: Complications and limitations of direct-current countershock. J.A.M.A. 190: $417, \quad 1964$.

91. Rall, T. W., and Sutherland, E. W.:
Formation of a cyclic adrenine ribonucleotide by tissue particles. J. Biol. Chem. 232 $1065,1958$.

92. Rall, T. W., and Sutherland, E. W.: Fractionation and characterization of a cyclic adenine ribonucleotide formed by tissue particles. J. Biol. Chem. 232:1077, 1958.

93. Reynolds, E.: Personal communication.

94. Riddle, D. H., Schull, L, G., Frist, T. F., and Baker, T. D.: Experience with pheochromocytomas in 21 patients: use of dichloroisoproterenol hydrochloride for cardiac arrhythmias. Ann. Surg. 157:980, 196:3.

95. Robin, E., Cowan, C., Puri, P., Cianguly, S., De Boyrie, E., Martinez, M., Stock, T., and Bing, R. J.: A comparative study of nitroglycerin and propranolol. Circulation $36: 175,1967$.

96. Rosell, S.: Release of free Rally acids from subcutaneous adipose tissue in dogs following sympathetic nerve stimulation. Acta Physiol. Scand. 67:343, 1966.

97. Ross, E. M., Robertson, P. G. C., and Watson, H.: Failure of oral propranolol to maintain relief from paroxysomal syncopal attacks in Fallot's tetralogy after its successful intravenous use. Lancet 2:945, 1966.

98. Rouse, W.: Effects of propranolol and ouabain on the conducting system of the heart in dogs. Amer. J. Cardiol. I8:406, 1966.

99. Rowlands, D. J., Howitt, G. and Markman, P.: Propranolol (Inderal) in disturbances of cardiac rhythm. Brit. Med. J. 1: $891,196.5$.

100. Salvador, R. A. and April, S. A.: Inhibition of fatty acid mobilization in experimental diabetes by $\mathrm{N}$-tertiary butyl methoxamine. Fed. Proc. 24:298 (abstract) 1965.

101. Schotz, M. C., and Page, I. H.: Effect of adrenergic blocking agents on the release of free fatty acids from rat adipose tissue. J. Lipid Res, 1:466, 1960,

102. Shah, P., and Kidd, I.: Circulatory effects of propranolol in children with Fallot's tetralogy. Observations with isoproterenol infusion, exercise and crying. Amer. J. Cardiol. 19:653, 1967.

103. Somani, P., Fleming, J, G., Chan, G. K., and Lum, B. K. B.: Antagonism of epinephrine-induced cardiac arrhythmias by 4-(2-isopropylamino-1-hydroxy-ethyl)-methanesulfonanilide (MJ 1999). J. Pharmacol. Exp. Ther, 151:32, 1966

104. Somani, P., and Lum, B. K. B.: 
The antiarrhythmic actions of leta-iadrenergic blocking agents. J. Pharmacol. Exp. Ther. 147:194, 1965.

105. Somani, P., and Lum, B. K. B.: Blockade of epinephrine- and ouabain-induced cardiac arrhythmias in the dog heartlung preparation. J. Pharmacol. Exp. Ther. $152: 235,1966$.

106. Sonnenblick, E. H., Braunwald, E., Williams, J. F., Jr., and Click, G.: Effects of exercise on myocardial force-velocity relations in intact unanesthetized man. Relitive roles of changes in heart rate, sympiathetic activity, and rentricular dimensions. J. Clin. Invest. 44:2051, 1965.

107. Sonnenblick, E. H., Ross, J., Jr., Covell, J. W., Kaiser, G. A., and Braunwald, E.: Velocity of contraction as a determinant of myocardial oxygen consumption. Amer. J. Physiol. 209:919, 1965.

108. Sowton, E., and Hamer, J.: Hemodynamic changes after beta-adrenergic blockade. Amer. J. Cardiol. 18:317, 1966.

109. Stickney, J. L.: On the relationship between catecholamines and digitalis-induced arrhythmias. Doctoral 'Thesis, The University of Michigan, 1967.

110. Stock, J. P. P., and Dale, N.: Betaadrenergic receptor blockade in cardiac arrhythmias. Brit. Med. J. 2:1230, 1963.

111. Stock, K., and Westermann, E.: Effects of adrenergic blockade and nicotinic acid on the mobilization of free fatty acids. Life Sci. 4:1115, 1965.

112. Sutherland, E. W.: The effect of the hyperglycemic factor of the pancreas and of epinephrine on glycogenolysis. Recent Progr. Hormone Res. 5:441, 1950.

113. Sutherland, E. W.: The relation of adenosine 3', 5'-phosphate and phosphorylase to the actions of catecholamines and other hormones. Pharmacol. Rev. 12:265, 1960.

114. Sutherland, E. W, and Robison, G. A.: Section II. Metabolic effects of catecholamines. A. The role of cyclic $3^{\prime}, 5^{\prime}$-AMP in responses to catecholamines and other hormones. Pharmacol. Rev. 18:145, 1966.

115. Ten Eick, R. E., Wyte, S. R., Ross, S. M., and Hoffman, B. F.: Post-countershock arrhythmias in untreated and digitaljzed dogs. Circ. Res. 21:375, 1967.

116. Tucker, M. J., Adcock, S. J., and Baker, S. B. deC: Absence of earcinogenic properties of propranolel in mice. Brit. Med. J. $2: 363,196.5$.

117. Vas, G. J.: Propranolol in Parkinsonian tremor. Amer. I. Carcliol. 18:484, 1966.

118. Vaughn Williams, E. MI.: Mode of action of beta receptor antagonists on cardiac muscle. Amer. J. Cardiol. 18:399, I966.

119. Wallace, A. C., Schall, S. F., Sugimoto, T., Rozear, M., and Alexander, J. A.: The electrophysiologic effects of betaadrenergic blockade and cardiac denervation. Bull. N. Y. Acad. Med. 43:1119, 1967.

120. Wertheimer, E., Hamosh, M., and Shafrir, E.: Factors affecting fat mobilization from adipose tissue. Amer. J. Clin. Nutr. 8:705, 1960.

121. Wertheimer, E., and Shapiro, B.: The physiology of adipose tissue. Physiol. Rev. 28:451, 1948.

122. White, J. E., and Engel, F. L.: A lipolytic action of epinephrine and norepinephrine on rat adipose tissue in vitro. Proc. Soc. Exp. Biol. Med. 99:375, 1958.

123. Whitsitt, L. S., and Lucchesi, B. R.: The cardiac beta-adrenergic receptor blocking actions of propranolol and its sterioisomers. Life Sici. 6:939, 1967.

124. Whitsitt, L. S., and Lucchesi, B. R.: Effects of propranolol and its sterioisomers upon coronary vascular resistance. Cire. Res. 21:305, 1967.

125. Whitsitt, L. S., and Lucchesi, B. R.: The effects of beta-idrenergic receptor blockade and glucagon on the atrioventricular transmission system. Circ. Res. (in press).

126. Wolfson, S., Heinle, R. A., Herman, M. V., Kemp, H. G., Sullivan, I. M., and Gorlin, R.: Propranolol and angina pectoris. Amer. J. Cardiol. 18:345, 1966.

127. Wolfson, S.. Robbins, S. I., and Krasnow, N.: Treatment of cardiac arrhythmias with beta-adrenergic blocking agents. Amer. Heart J. 72:177, 1966.

128. Wood, P.: Attacks of deeper cyanosis and loss of consciousness (syncope) in Fallot's tetralogy. Brit. Heart J. 20:282, 1958.

129. Wool, I. G., Goldstein, M. S., Ramey, E. R., and Levine, R.: Role of epinephrine in the physiology of fat mobilization. Amer. I. Physiol. 178:427, 1954.

130. Zuberbuhler, R. C., and Bohr, D. F.: Responses of coronary smooth muscle to catecholamines. Circ. Res. 16:431, 1965. 